\title{
Tarımsal Gıda Sistemlerinin Do̊nưșưmů? İzmir'de Alternatif Tarımsal Gıda Girişimlerinin Keşfi
}

\author{
Dalya Hazar* \\ Seda Senem Alpaykut Bayrak**
}

Günümüzde kır ve kenti birbirine bağlayan en önemli husus kuşkusuz gıdadır. Gıda bugün daha önce hiç olmadığı kadar popüler ve çeşitlenmiş durumdadır. Dünyada olduğu gibi Türkiye'de de tüketim pratikleri çok görünür hale gelmiştir. Dr. Emel Karakaya Ayalp, tarımsal gıda sistemlerinin dönüşümünü sorgulayarak İzmir'de üç adet niş inisiyatife odaklandığı, "Agro Food System Transitions? Exploring Alternative Agro Food Initiatives in İzmir, Turkey" (Tarımsal Gıda Sistemlerinin Dönüşümü? İzmir, Türkiye'de Alternatif Tarımsal Gıda Girişimlerinin Keşfi) başlıklı araştırmasında, kentlerin sürdürülebilir yönde dönüşümünü ve mevcut tarımsal gıda sistemine alternatif olarak ortaya çıkmakta olan pratikleri incelemiştir. Bu çalışma, Rejim Teorisi ve Çok-Düzeyli Perspektif çerçevelerine dayanarak, ilgili inisiyatifleri birer stratejik niş olarak ele almakta ve bu nişlerin gelişim süreçlerini soruşturmaktadır. Karakaya Ayalp'in çalışması, Türkiye'de yeni ortaya çıkmakta olan alternatifleri ve bu alternatiflerin dönüşümünü nişlerin İzmir'deki gelişmeleri ile bağlantılı biçimde ortaya koymaktadır.

Yazara göre, özellikle 1970'li yıllardan sonra şiddetlenen neoliberal politikalarla tarımsal üretimin küresel tarımsal gida zincirlerine kitlesel ve hızlı biçimde entegrasyonu, tarla ile sofra arasındaki mesafeyi uzaklaştırmıştır. Yanı sıra, İkinci Dünya Savaşı sonrasında ortaya çıkan tarımda kimyasallaşma, endüstrileşme ve makineleşme süreçlerinin ekolojik sonuçları; hayvan refahına, toplum sağlığına, kırda çalışma koşullarına ve emek piyasasına yönelik kayg1lar; obezite ve yetersiz beslenmeye yönelik dünyanın farklı yarım kürelerindeki eşitsizlikler; iklim değişikliğinin gittikçe daha yıkıcı sonuçları görünür kılması vb. sorunlar, tarımsal gıda sistemi içerisinde farklı örgütlenmelerin ortaya çıkmasına neden olmuştur. Bu örgütlenmeler üretici ve tüketicileri doğrudan birbirine bağlayan ve gıda üretim-tüketim-dağıtım sistemlerinde yeni ve özgün pratikleri içeren "Alternatif Tarımsal Gıda Sistemi"nin (AGS), 2000 sonrasında Türkiye'de de yaygınlaşmasını; özellikle Ankara, İzmir ve İstanbul gibi metropoliten kentlerde çeşitli pratiklerle ortaya çıkmasını sağlamıştır.

AGS ana akım, endüstriyel ya da konvansiyonel gida üretim, tüketim ve tedarik sistemine karşı, üreticileri, tüketicileri ve ilgili diğer aktör gruplarının oluşturduğu alternatif ağları ve örgütlenmeleri tanımlayan bir terimdir. $\mathrm{Bu}$ açıdan, endüstriyel ve/veya konvansiyonel üretim, tüketim ve dağıtım mekanizmaları ile güncel gıda rejimi olan Küresel Şirketleşmiş Gıda Rejimi'nin pratiklerine karşı duran, farklı biçimlerde örgütlenmiş çeşitli inisiyatifleri ve tarım-gıda hareketlerini içermektedir. AGS, Alternatif Gıda Ağları (AGA) ve Alternatif Gıda İnisiyatifleri (AGİ) özdeş olmayan ancak belirli düzeylerde ve biçimlerde ortaklaşan organik/ekolojik üretim ve tüketim ağları, üretici kolektifleri, tarımsal zanaat ağları, yerel gıda ağları, kentsel tarım ağları vb. çok sayı-

\footnotetext{
* TMMOB Şehir Plancıları Odası İzmir Şubesi

** Bolu Abant İzzet Baysal Üniversitesi, Şehir ve Bölge Planlama Bölümü
} 
da ağlaşmış yapının kolektifleşmiş isimler dizisidir.

Bu çalışma, keşifçi niteliksel çoklu vaka araştırması ile bir mezo-seviye inceleme, tarımsal gıda sistemi belgeleme ve Türkiye'deki Alternatif Tarımsal Gıda İnisiyatiflerine yönelik mikro-seviyede bir inceleme sunmaktadır. Çoklu vaka araştırmasında Türkiye'de farklı kentlerde ortaya çıkmış olan 40 adet mikro-seviye soruşturması İzmir'deki üç ayrı niş inisiyatifte yapılmaktadır: (1) Üretici inisiyatifi olarak Gödence Tarımsal Kalkınma Kooperatifi, (2) tüketici inisiyatifi olarak Batı İzmir Topluluk Destekli Tarım Grubu (BİTOT) ve (3) üretici-tüketici müşterekliği olarak Foça Yeryüzü Pazarı. Vaka çalışmalarının İzmir'de yer alıyor olması, nişlerin ortaya çıkışı ve gelişimi bağlamında kentsel seviyede bir sorgulamaya olanak tanımıştır.

Karakaya Ayalp, bu çalışma ile yazındaki ve meslek alanındaki çeşitli boşlukları doldurmuştur. Öncelikle, AGS'nin içinde ortaya çıkmakta olan ve Türkiye yazınında neredeyse tamamen görmezden gelinen niş inisiyatifleri incelemiştir. Araştırmada, Türkiye'de çeşitli kentlerde ve bölgelerde ortaya çıkış 40 adet niş inisiyatif yaygın araştırma sürecinde incelenerek bir mezo-düzey analiz yapılmış, bu inisiyatifler arasında üç tanesi yoğun araştırma için seçilerek bir mikro-düzey araştırma yürütülmüştür. Seçilen yoğun araştırma vakaları, İzmir'de kent ölçeğinde bir araştırma yapmaya olanak vermiştir ve çalışma bu bakımdan kent-ölçeğinde AGS'nin dönüşümünü sorgulamaya da olanak sağlamıştır. Ayrıca, yazar, AGS araştırmaları çerçevesinde dünya yazınında eksikliği eleştiri konusu olan mikro düzey inceleme kapsamında, Türkiye örneği üzerinden araştırmalara katkıda bulunmuştur.

Çoklu vaka araştırmasında Türkiye'de farklı kentlerde ortaya çıkmış 40 adet mikro-seviye soruşturması, Türkiye'de AGS'nin tarihsel gelişimine, ortaya çıktığ1 koşullara, Alternatif Gıda İnisiyatiflerinin niteliklerine ve gelişme süreçlerine ilişkin bulguları ortaya koymaktadır. İzmir'de üç adet niş inisiyatife odaklanan vaka çalışması ise farklı pratiklerin gelişim sürecini ve niteliklerini çok düzeyli perspektife dayanarak ve mevcut tarımsal politikalar ve tarımsal gıda sistemi ekseninde incelemiştir.

Çalışmanın sonuç bölümünde, üretici inisiyatifi olarak ele alınan Gödence Tarımsal Kalkınma Kooperatifi, "yerleşik rejim” ile uyumluluk gösteren bir niş olarak ortaya çıkmıştır. Bu uyumluluk hali, çeşitli yapısal nedenler ve izlek bağımlılıkları nedeniyle nişin yenilikçi kapasitesini köreltmiştir. İzlek bağımlılıklarının sabitleşmesi, sosyo-teknik pratiklerin yayılmasını engeller nitelikte bir eğilim yaratmıştır. Çok düzeyli perspektif yazınının ortaya koyduğu ve nişlerin yenilikçilik kapasitesini belirten üç başlık (1) sosyo-teknik düzenlemelerde özgünlük, (2) yerel bağlama cevap verebilirlik ve (3) ana akım rejim pratiklerine karşı korunma bağlamında, Gödence, incelenen vakalar arasında ana akım rejim ile en çok uyumlanmış vaka olarak ortaya çıkmıştır. Bu durumun ardında, diğer nişlerden farklı olarak 1970'li yıllarda ortaya çıkmış olması, üreticileri olumsuz etkileyen tarımsal politika değişimlerine çok açı olması, piyasa fiyatlarındaki dalgalanmalar, yaşlanan kır nüfusu, genç nüfusun düşük gönüllülük oranı, iklim değişikliği gibi çok sayıda yapısal gerekçe bulunmaktadır. Tezin bulguları göstermektedir ki Gödence, ana akım rejim ile tamamen uyumlanma riskini gösteren bir nişe dönüşmüştür.

Diğer taraftan BITOT ve Foça Yeryüzü Pazarı yeni nişlerin oluşumuna kaynaklık etmiştir. Buğday Derneği'nin yaratıcı kapasitesi, gönüllülüğü genişletmekteki becerisi ve mevcut ağları, BİTOT için sosyo-teknik pratikler yaratacak, tasarlayacak ve uygulayacak bir gönüllüler ağı sağlamıştır. Tüketici inisiyatifi olarak 2014'te ortaya çımış olan BITOT, sistemli olarak yeni sosyo-teknik pratikler üretmiş ve gönüllü kapasitesini geliştirmiştir. Alternatif rejim kurallarını 
adım adım geliştirmek ve sorunlar ya da krizler karşısında vakaya yönelik çözümler üretip yerel aktörlerle işbirliği yapmak, sosyal medya vb. araçları kullanmak, örgütlenmeyi genişletmek ya da niş pratikleri ile örgütlenmeyi yeniden tasarlamak BİTOT'un bir niş olarak nitel derecesini yükseltmesini sağlamış ve yeni nişler olan Gediz Ekoloji Topluluğu (GETO) ve Homeros'un kuruluşlarında kolaylaştırıcılığa kaynaklık etmiştir.

Foça Yeryüzü Pazarı'nın kendine mahsus yenilikçi kapasitesi, alternatif sosyo-teknik pratikler yaratırken, yerleşik rejimin kurumlarını ve aktörlerini maharetli biçimde kullanmasında yatmaktadır. Üretici-tüketici müşterekliğinin örneği olarak incelenen Foça Yeryüzü Pazarı, Yavaş Gıda (Slow Food) küresel hareketinin yerel bir örgütüne bağlı olarak 2011'de kurulmuş, 2012'de "Yeryüzü Pazarı" statüsü kazanmış ve 2014'te dünyanın en iyi Yeryüzü Pazarı seçilmiş; özgün ve yenilikçi sosyo teknik pratikler ile uluslararası ağ yapılarına dahil olmuş önemli bir niştir. Rejim kuralları Yavaş Gıda Hareketi tarafından belirlenmiş olan niş; esneyebilir yapısı ile işbirliğiyle öğrenme, sosyal ağlaşma, yerel aktörleri dahil etme, ekosistem ve kültürel birikimin korunması gibi çok sayıda stratejiye yönelik sistematik eylemler üreterek gelişmiş ve İstanbul Şile Yeryüzü Pazarı'nın kurulmasına destek olarak yeni nişlere kaynaklık etmiştir.

Yazar araştırmasını Türkiye'de daha önce ele alınmamış, yazında yer almayan ve hakkında bir internet sayfası dahi olmayan bir konuda tamamlamıştır. Bu bakımdan çalışma, açıklayıcı ya da betimleyici değil, keşifsel bir araştırmadır. Yazarın tez çalışmasını tamamladığ 12016 'nın ilerleyen aylarında Ekvador'un Quito kentinde gerçekleştirilen HABITTAT III toplantılarında kentlerin tarımsal gıda sistemlerinin sürdürülebilir dönüşümü ve kentlerin gıda planlaması üzerine tartışmalar gerçekleştirilerek kararlar alınmıştır. Bu bağlamda, çalışma dünya gündeminde güncel olarak yer bulan ve Kent Planlama meslek disiplininin sorumluluk alanına yeni dahil edilmiş kentsel gıda planlaması konusuna ve ortadan kalkmakta olan kent-kır ikiliğine koşut tarımsal üretim-dağıtım-tüketim sistemlerinin Türkiye'deki alternatif örgütlenme pratiklerine dair çok önemli tespitler sunmaktadır.

Emel Karakaya, "Agro Food System Transitions? Exploring Alternative Agro Food Initiatives in İzmir, Turkey” (Doktora Tezi, İzmir Yüksek Teknoloji Enstitüsü, 2016). 